Cell Research (2002); 12(2):143-150

http://www.cell-research.com

\title{
Recombinant scorpion insectotoxin AaIT kills specifically insect cells but not human cells
}

\author{
Sheng Jian JI, Feng LIU, ER Qiu LI, Yu Xian ZHU* \\ The National Laboratory of Protein Engineering and Plant Genetic Engineering, College of Life Sciences, Peking \\ University, Beijing 100871, China
}

\begin{abstract}
The nucleotide sequence deduced from the amino acid sequence of the scorpion insectotoxin AaIT was chemically synthesized and was expressed in Escherichia coli. The authenticity of this in vitro expressed peptide was confirmed by N-terminal peptide sequencing. Two groups of bioassays, artificial diet incorporation assay and contact insecticidal effect assay, were carried out separately to verify the toxicity of this recombinant toxin. At the end of a $24 \mathrm{~h}$ experimental period, more than $60 \%$ of the testing diamondback moth (Plutella xylostella) larvae were killed in both groups with $\mathrm{LC}_{50}$ value of $18.4 \mu \mathrm{M}$ and $0.70 \mu \mathrm{M}$ respectively. Cytotoxicity assay using cultured Sf9 insect cells and MCF-7 human cells demonstrated that the toxin AaIT had specific toxicity against insect cells but not human cells. Only $0.13 \mu \mathrm{M}$ recombinant toxin was needed to kill $50 \%$ of cultured insect cells while as much as $1.3 \mu \mathrm{M}$ toxin had absolutely no effect on human cells. Insect cells produced obvious intrusions from their plasma membrane before broken up. We infer that toxin AaIT bind to a putative sodium channel in these insect cells and open the channel persistently, which would result in $\mathrm{Na}^{+}$influx and finally cause destruction of insect cells.
\end{abstract}

Key words: Scorpion toxin, AaIT, prokaryotic expression, cytotoxicity.

\section{INTRODUCTION}

Scorpion venom is one of the most important tools for scorpions to predate and to exercise self-defense. The effective components of the venom are a group of proteins composed of 30-80 amino acids which possess neurotoxicity[1]. Ion channels are the main targets for various neurotoxins[2]. The scorpion toxins can be classified mainly into two major categories according to their sizes and pharmacological target sites: the short-chain toxins composed of 31-37 amino acids and bridged by three or four disulfide bonds that affect mainly $\mathrm{K}^{+}$channels, and the longchain toxins composed of 60-70 amino acids and bridged by four disulfide bonds that affect mainly $\mathrm{Na}^{+}$channels[3-5]. The long-chain insect toxins can

* Corresponding author: Tel: +86-10-62751193; Fax: +86-1062754427; E-mail: Zhuyx@water.pku.edu.cn

Received March-11-2002? Revised April-18-2002? Accepted April-20-2002 be further subdivided into two groups: the depressant toxins and the excitatory toxins[6]. The former induces a progressive flaccid paralysis of insects by blocking the action potentials[7], and is represented by BmK IT4, Aa IT5, Ba IT2, Bot IT4 and Bot IT5, Bj IT2, Lqh IT2, and Lqq IT2[1], [8-13]. The later causes an immediate spastic paralysis of insects by inducing repetitive firing in the motor nerves[14], and is represented by AaIT, Bj IT1, Bjxtr IT, Lqq IT1, Amm IT, Lqh IT1 [12],[13], [15-17].

The insect toxin AaIT (Androctonus australis Hector Insect Toxin) is produced by the highly toxic scorpion Androctonus australis Hector and is among the first toxins purifieded from scorpion venom. AaIT is an excitatory long-chain toxin specific to insects and is composed of 70 amino acids with four disulfide bridges[18],[19]. The specificity of AaIT to insects was revealed both at the organism level and 
the tissue level[20]. Here we carried out in vitro cell toxicity assay to explore the selectivity of AaIT to cultured insect cells. In vitro cell toxicity assay is commonly used in toxicity assessment since it is not only simple, sensitive, economical and homogeneous, but also it has ethical advantages for it is animalfree[21]. In the current work, we evaluated the toxicity of bacterially expressed AaIT to diamondback moth larvae as well as to cultured cell lines. We verify that the prokaryotically expressed toxin has apparent specific toxicity only to insect cells, but not to human cells.

\section{MATERIALS AND METHODS}

\section{Materials, strains and plasmids}

All chemicals and reagents were of analytical grade purchased from Promega (USA), Sigma (USA), TaKaRa (Japan) or SABC (China). Restriction enzymes, T4 DNA Ligase, Klenow fragment and plasmid purification kit were from Promega (USA). DNA gel extraction kit were from QIAGEN (Germany). Sephacryl S-100 HR was from Amersham Pharmacia (Sweden). CellTiter 96®Queous One Solution Cell Proliferation Assay Reagent was from Promega (USA). RPMI 1640 medium and Grace' s insect medium (supplemented) were both from GIBCO BRL (USA). E.coli strain DH5a and HB101 were used for plasmid construction, propagation and prokaryotic expression. MCF-7 human breast-tumor cells were stored in our laboratory and Sf9 insect cells (from Spodoptera frugiperda ovary) were kindly given to us by Professor Meihao $\mathrm{Hu}$ at our university. The temperature-induced, non-fusion expression vector $\mathrm{pBV} 220$, which contains $\mathrm{P}_{\mathrm{R}} \mathrm{P}_{\mathrm{L}}$ promoter, was kindly given to us by Professor Zhiqing Zhang[22]. Insect larvae were purchased from Chinese Academy of Agricultural Sciences. DNA synthesis and DNA sequencing were commercially done by GIBCO BRL (USA) and Shanghai BioAsia Company (China) respectively. Peptide N-terminal sequencing was carried out by our laboratory.

Synthesis of the full-length AaIT coding sequence, construction of cloning vector and prokaryotic expression vector

We designed and synthesized four partially complementary oligonucleotides (A1, A2, A3 and A4) according to the nucleotide sequence reported previously[19](Fig 1A), and obtained the entire AaIT coding sequence through annealing and filling (Fig 1B and Fig 1C). Full-length AaIT coding sequence was cloned into pBluescript II SK to produce the vector pBS-AaIT. The identity of the synthetic gene was verified by DNA sequencing and the coding sequence was then cloned into expression vector $\mathrm{pBV} 220$. The authenticity of the constructed expression vector $\mathrm{pBV} 220 / \mathrm{AaIT}$ was confirmed by DNA sequencing again.

\section{Large-scale expression and purification of recombi-}

\section{nant AaIT protein}

About 5-6 g of frozen DH5a cell pellets expressing the AaIT toxin were resuspended in $30 \mathrm{ml} \mathrm{TN}$ buffer $(50 \mathrm{mM}$ Tris- $\mathrm{HCl}$, $\mathrm{pH} 7.5,150 \mathrm{mM} \mathrm{NaCl}, 1 \mu \mathrm{M} \mathrm{MgCl}_{2}$ ) with $35 \mu \mathrm{g} / \mathrm{ml}$ DNase I added. The lysate was sonicated thoroughly. The inclusion bodies were pelleted and resuspended in $20 \mathrm{ml} \mathrm{TN}$ buffer. The pellets were washed and resuspended in denaturing buffer [5.6 M guanidine hydrochloride, $100 \mathrm{mM}$ Tris-HCl, pH8.0, $1 \mathrm{mM}$ EDTA and $1 \mathrm{mM}$ dithiothreitol (DTT) dissolved in degassed sterile H2O] by gentle agitation for $6-16 \mathrm{~h}$ at $4 \mathrm{oC}$. The solubilized protein was rapidly diluted 1:25 into degassed refolding buffer [final concentrations: 100 mM Tris-HCl, pH 8.0, 1m M EDTA, 40 mM DTT, $1 \mathrm{mM} \mathrm{ZnCl}_{2}$, $280 \mathrm{mM}$ guanidine hydrochloride, $500 \mathrm{mM}$ L-arginine, $2 \mathrm{mM}$ glutathione (GSH), $1 \mathrm{mM}$ glutathione disulfide (GSSG)] and allowed to refold for $24 \mathrm{~h}$ at $4^{\circ} \mathrm{C}[23]$. The sample was concentrated and desalted by ultrafiltration with a $1 \mathrm{~K}$ Mini-Ultrasette system (Pall Gelman, USA). Insoluble debris and misfolded proteins were then removed by centrifugation $(8000 \times \mathrm{g}, 15 \mathrm{~min})$ and the supernatant was loaded onto Sephacryl S-100 HR resin pre-equilibrated with $0.01 \mathrm{M} \mathrm{NH}_{4} \mathrm{HCO}_{3}$. The toxin was eluted with the same buffer. Fractions were collected and lyophilized to dryness. The recombinant toxin was separated by electrophoresis through a $15 \%$ polyacrylamide gel and stained by Coomassie Blue.

\section{$N$-terminal peptide sequencing of recombinant toxin AaIT}

The purified recombinant toxin AaIT was loaded onto a $15 \%$ polyacrylamide gel and then transferred from the gel to PVDF membrane in a CAPS buffer system (100 mM CAPS, 10\% methanol, pH11). The membrane was stained for $3 \mathrm{~min}$ in Coomassie Blue R-250 solution (1\% Coomassie Blue R-250, 50\% methanol, $1 \%$ acetic acid) and then destained in $50 \%$ methanol till the protein band appeared. Peptide sequencing was carried out on Applied Biosystem 491 Protein Sequencer.

\section{Bioassays of prokaryotically expressed toxin AaIT}

The recombinant toxin AaIT was dissolved in distilled water and then diluted consecutively to produce $0.02,0.2,2,20$, and 40 $\mathrm{mM}$ toxin solutions. Insect bioassays were carried out using early third instar diamondback moth larvae.

Artificial diet incorporation assay. Fresh cabbage leaves were first treated with absorbent cotton to remove the wax present on the surface before being cut into leaf disks (F $1.5 \mathrm{~cm}$ ) and soaked into the toxin solutions for 10 seconds. The leaf disks were then air-dried and fed to the diamondback moth larvae in culture dishes (5 leaf disks per 10 larvae). The assay on each concentration point was repeated for 4 times. The dishes were placed in the light incubator $\left(25 \pm 1^{\circ} \mathrm{C}, 16 \mathrm{~L}: 8 \mathrm{D}\right)$ for $24 \mathrm{~h}$. Dead larvae were counted at the end of $24 \mathrm{~h}$ experimental period.

Contact insecticidal effect assay. The larvae were soaked in various toxin solutions for 5 seconds and were then placed on filter paper to absorb the extra moisture. The treated larvae were placed in the culture dishes and fed with fresh cabbage leaves. The assay on each concentration point was carried out with 10 larvae 
and was repeated for 3 times. Dead larvae were counted at the end of $24 \mathrm{~h}$ experimental period.

\section{Construction of the standard curve for cell number}

Various numbers of Sf9 insect cells and MCF-7 human cells $\left(1 \times 10^{4}, 2 \times 10^{4}, 4 \times 10^{4}, 6 \times 10^{4}, 8 \times 10^{4}, 10 \times 10^{4}, 12 \times 10^{4}, 14 \times 10^{4}, 16 \times 10^{4}\right.$, $18 \times 10^{4}, 20 \times 10^{4}$ cells) were added to the wells of a 96 -well plate, followed by adding the medium (TNM-FH medium for Sf9 cells and RPMI 1640 medium for MCF-7 cells, both containing $10 \%$ FBS) to give the final volume of $100 \mu \mathrm{l}$. The cultures were allowed to equilibrate for $1 \mathrm{~h}$ before $20 \mu \mathrm{l}$ /well of CellTiter $96{ }^{\circledR}$ AQueous One Solution Reagent was added. After $1 \mathrm{~h}$ incubation (Sf9 cells at $27^{\circ} \mathrm{C}$ in a normal atmosphere, and MCF- 7 cells at $37^{\circ} \mathrm{C}$ in a $5 \%$ $\mathrm{CO}_{2}$ atmosphere), the absorbance at $490 \mathrm{~nm}$ was recorded using a microplate reader (Bio-Rad, USA). The standard curve for cell number was drawn with cell number per well on $\mathrm{X}$ axis and absorbance at $490 \mathrm{~nm}$ on $\mathrm{Y}$ axis.

Cytotoxicity assays of recombinant toxin AaIT to Sf9 insect cells and to MCF-7 human cells

1羚 104 Sf9 and MCF-7 cells were added to the wells of a 96 well plate seperately. The wells contained $100 \mu$ leither TNM-FH growth media or RPMI 1640 growth media with $0,0.00026,0.00052,0$. $0026,0.013,0.026,0.13,0.26$ or $1.3 \mu \mathrm{M}$ toxin added. The plates were incubated for $48 \mathrm{~h}$ before $20 \mu \mathrm{l}$ of CellTiter $96{ }^{\circledR}$ AQueous One Solution Reagent was added to each well. After 1-4 h of further incubation, the absorbance at $490 \mathrm{~nm}$ was recorded using a microplate reader (Bio-Rad). The cytotoxicity assay for each of the two cell lines was done in triplicates.

\section{RESULTS}

Expression of recombinant AaIT in E.coli
Upon induction by transferring the culture from $30^{\circ} \mathrm{C}$ to $42^{\circ} \mathrm{C}$, a protein of $\sim 7 \mathrm{kDa}$ identical to the deduced molecular weight of the toxin was expressed in E.coli strains harboring the plasmid pBV220/ AaIT (Fig 2, lanes 2-5). The expression reached its maximum level after $8 \mathrm{~h}$ high temperature treatment with no more apparent increase in $10 \mathrm{~h}$ (Fig 2, lanes 4-5).

Purification and sequence identification of the recombinant toxin AaIT

Preliminary experiments showed that most of the toxin produced in E.coli was localized in inclusion bodies (data not shown). The recombinant protein was purified via ultrafiltration followed by Sephacryl S-100 HR gel filtration and was finally lyophilized to dryness. A small fraction of the powder was dissolved in distilled water and was loaded onto a $15 \%$ polyacrylamide gel (Fig 2, lane 7). Gel-purified recombinant toxin AaIT was subjected to automated protein sequence analysis. The first eight cycles of an Edman degradation gave the sequence Met-LysLys-Asn-Gly-Tyr-Ala-Val, which was identical to the amino acid sequence deduced from nucleotide sequence (Fig 1C). Though the recombinant toxin starts with an additional Met residue compared with the native toxin, it is unlikely to affect the function of AaIT because it is $\mathrm{N}$-terminal.

Tab 1. Results of artificial diet incorporation assay

\begin{tabular}{ccccc}
\hline $\begin{array}{c}\text { Toxin concentration } \\
(\mu M)\end{array}$ & $\begin{array}{c}\text { Number of total } \\
\text { testing larvae }\end{array}$ & $\begin{array}{c}\text { Number of } \\
\text { dead larvae }\end{array}$ & $\begin{array}{c}\text { Mortality } \\
(\%)\end{array}$ & $\begin{array}{c}\text { Adjusted mortality } \\
(\%)\end{array}$ \\
\hline 0.02 & 40 & 2 & 5 & 0 \\
0.2 & 40 & 3 & 7.5 & 0 \\
2 & 40 & 9 & 22.5 & 16.2 \\
20 & 36 & 20 & 55.6 & 52.0 \\
40 & 40 & 26 & 65 & 62.2 \\
Control & 40 & 3 & 7.5 & 0 \\
\hline Regression equation $(\mathrm{y}=\mathrm{a}+\mathrm{bx})$ & & $\mathrm{y}=2.32+1.00 \mathrm{x}, \mathrm{LC}_{50}=18.40 \mu M$ \\
\hline
\end{tabular}

Tab 2. Results of contact insecticidal effect assay

\begin{tabular}{ccccc}
\hline $\begin{array}{c}\text { Toxin concentration } \\
(\mu M)\end{array}$ & $\begin{array}{c}\text { Number of total } \\
\text { testing larvae }\end{array}$ & $\begin{array}{c}\text { Number of } \\
\text { dead larvae }\end{array}$ & $\begin{array}{c}\text { Mortality } \\
(\%)\end{array}$ & $\begin{array}{c}\text { Adjusted mortality } \\
(\%)\end{array}$ \\
\hline 0.02 & 30 & 12 & 40 & 35.7 \\
0.2 & 30 & 14 & 46.7 & 42.9 \\
2 & 31 & 18 & 58.1 & 55.1 \\
20 & 30 & 20 & 66.7 & 64.3 \\
Control & 30 & 2 & 6.7 & 0 \\
\hline Regression equation $(\mathrm{y}=\mathrm{a}+\mathrm{bx})$ & \multicolumn{3}{c}{$\mathrm{y}=4.69+0.25 \mathrm{x}, \mathrm{LC}_{50}=0.70 \mu M$} \\
\hline
\end{tabular}


A Oligo A1: 5'-CTCGAGAATTCTCTAGAATGAAAAAAAACGGCTACGCCGT GGATAGCAGCGGCAAAGCCCCGGAATGCCT-3'

Oligo A2: 5'-GTAGCCTTTATCGGCGTAATGCACTTTCGTGCACTGGTTG TTGCAGTAGTTGCTCAGCAGGCATTCCGGG-3'

Oligo A3: 5'-GATAAAGGCTACTGCTGCCTGCTGAGCTGCTACTGCTTTG GCCTGAACGATGATAAAAAAGTGCTGGAAA-3'

Oligo A4: 5'-CTGCAGAGATCTTAGTTAATAATCGTCGTATCGCAGTAGC TTTTGCGCGTATCGCTAATTTCCAGCACTT-3'

B
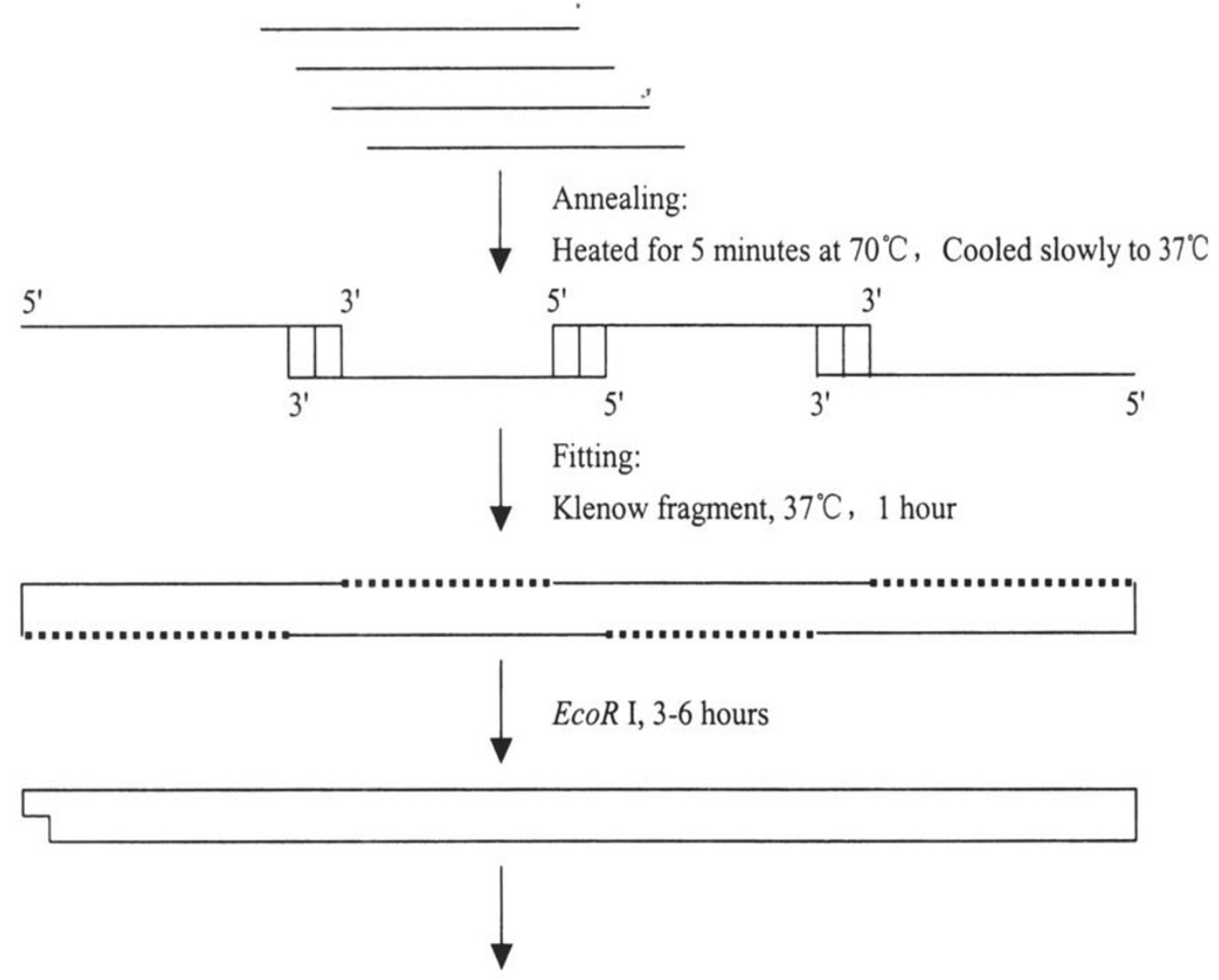

Cloned into pBluescript II SK (EcoR I/Sma I digested) 


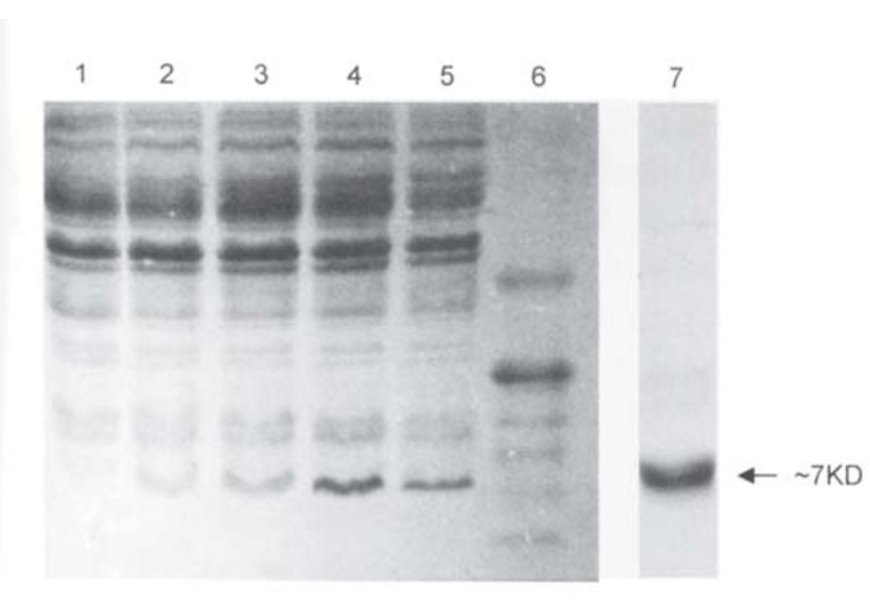

Fig 2. 15\% SDS-PAGE analysis of the in vitro expressed recombinant AaIT toxin. Lanes 1-5: cell lysates harvested at $0,4,6,8,10 \mathrm{~h}$ after $42^{\circ} \mathrm{C}$ induction. Lane 6: protein molecular weight markers (Promega). Lane 7: recombinant AaIT purified via gel filtration.

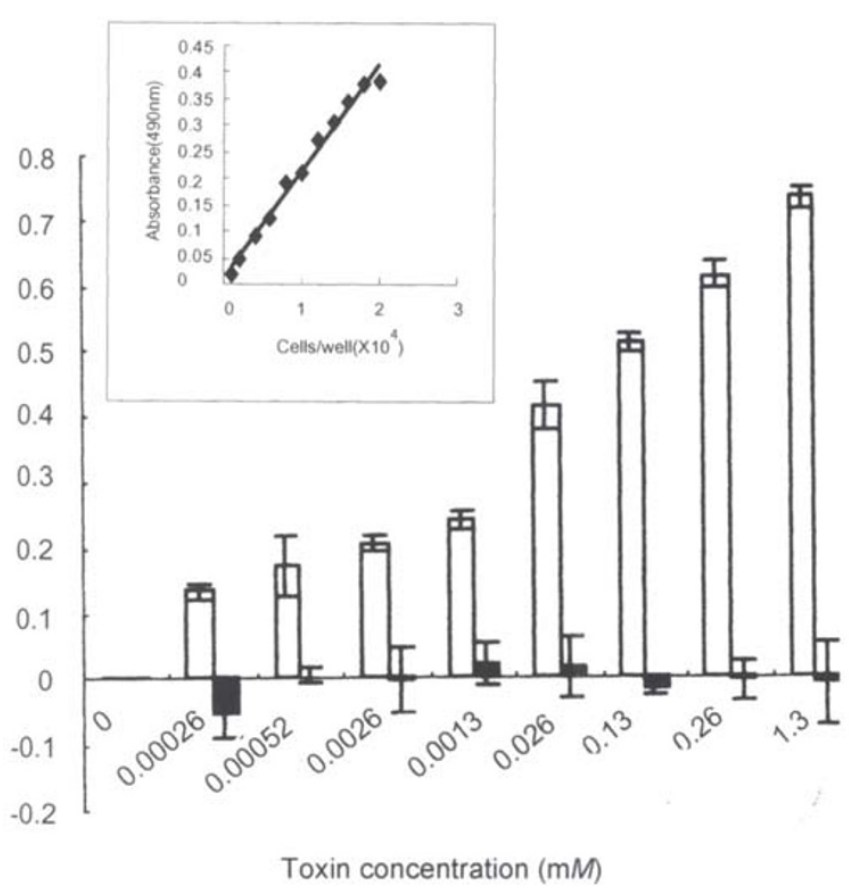

Fig 3. Mortality studies of Sf9 insect cells and MCF-7 human cells with different concentrations of the toxin AaIT. Inset: the standard curve showing that the number of cultured Sf9 insect cells functions linearly with the absorbance at 490 nm.(Legend: $\square$ f9, $\square \mathrm{MCF}-7$ )

$\triangleleft$ Fig 1. Cloning of the AaIT coding sequence by bridging the synthesized oligonucleotides. A: four oligonucleotides used to produce full-length AaIT sequence; B: strategy for constructing the toxin coding sequence; C: completed full-length AaIT sequence.
Bioassays using prokaryotically expressed toxin AaIT

Very different toxicities were observed as the result of two different bioassays. In the artificial diet incorporation assay, no larvae were killed by feeding leaves treated with solutions containing less than $0.2 \mu \mathrm{M}$ toxin (Tab 1). By contrast, in contact insecticidal effect assay, we observed significant amount of dead larvae with as low as $0.02 \mu \mathrm{M}$ toxin (Tab 2). The median lethal concentration (LC50) of the two assays was $18.40 \mu \mathrm{M}$ and $0.70 \mu \mathrm{M}$, respectively.

Cytotoxicity assays of recombinant toxin AaIT to Sf9 insect cells and to MCF-7 human cells

We first constructed a standard curve to show that there was a linear response between cell number and absorbance at 490nm (Fig 3, inset). The background absorbance shown at 0 cell/well was subtracted from each data point. In the cytotoxicity assay, the cell number in each well was calculated by the absorbance at $490 \mathrm{~nm}$ according to the standard curve. The mortality curve was drawn with toxin concentrations on $\mathrm{X}$ axis and cell mortality on $\mathrm{Y}$ axis. About $50 \%$ of insect cells were killed in a toxin concentration of $0.13 \mu \mathrm{M}$ in $48 \mathrm{~h}$, and all MCF7 human cell survived even in a toxin concentration as high as $1.3 \mu \mathrm{M}$ (Fig 3), which demonstrated that the cytotoxicity of the toxin to human cells must have been extremely low.

We also observed a change in the morphology of insect cells after $48 \mathrm{~h}$ toxin treatment. At the beginning of the experiment, both insect and human cells were spherical (Fig 4A, D). However, when toxin was included in the growth media, many insect cells produced obvious intrusions from their plasma membrane as shown in the inset of Fig 4B. These cells broke up into pieces very rapidly with longer incubation time or with increasing toxin concentrations in the media (Fig 4A, B, C). Human cells did not produce any obvious intrusions throughout the whole experiment (Fig 4D, E, F).

\section{DISCUSSION}

We constructed originally an efficient system for the expression of a scorpion toxin AaIT coding sequence in E.coli and carried out three different bioassays to study the toxicity of this recombinant 
protein. Interestingly, the median lethal concentration $\left(\mathrm{LC}_{50}\right)$ for the three assays differed by more than two orders of magnitude (Tab 1 and 2, Fig 3). Comparing with an $\mathrm{LC}_{50}$ of $0.13 \mu \mathrm{M}$ observed in cultured insect cells and an $\mathrm{LC}_{50}$ of $0.7 \mu \mathrm{M}$ observed in the contact insecticidal effect assay, low toxicity with an $\mathrm{LC}_{50}$ of $18.4 \mu \mathrm{M}$ was recorded in artificial diet incorporation assay in which the toxin was consumed by the testing insect through feeding. We suggested that this might be a result of toxin degradation by digestion. This raised an important question regarding agricultural application of the toxin. According to our calculation, $18.4 \mu \mathrm{M}$ toxin spread on the leaf surface equaled to $0.04 \%$ toxin protein expressed in the leaves (suppose total leaf protein content is 3 . $0 \%$ ). This was comparable to the level previously ob-

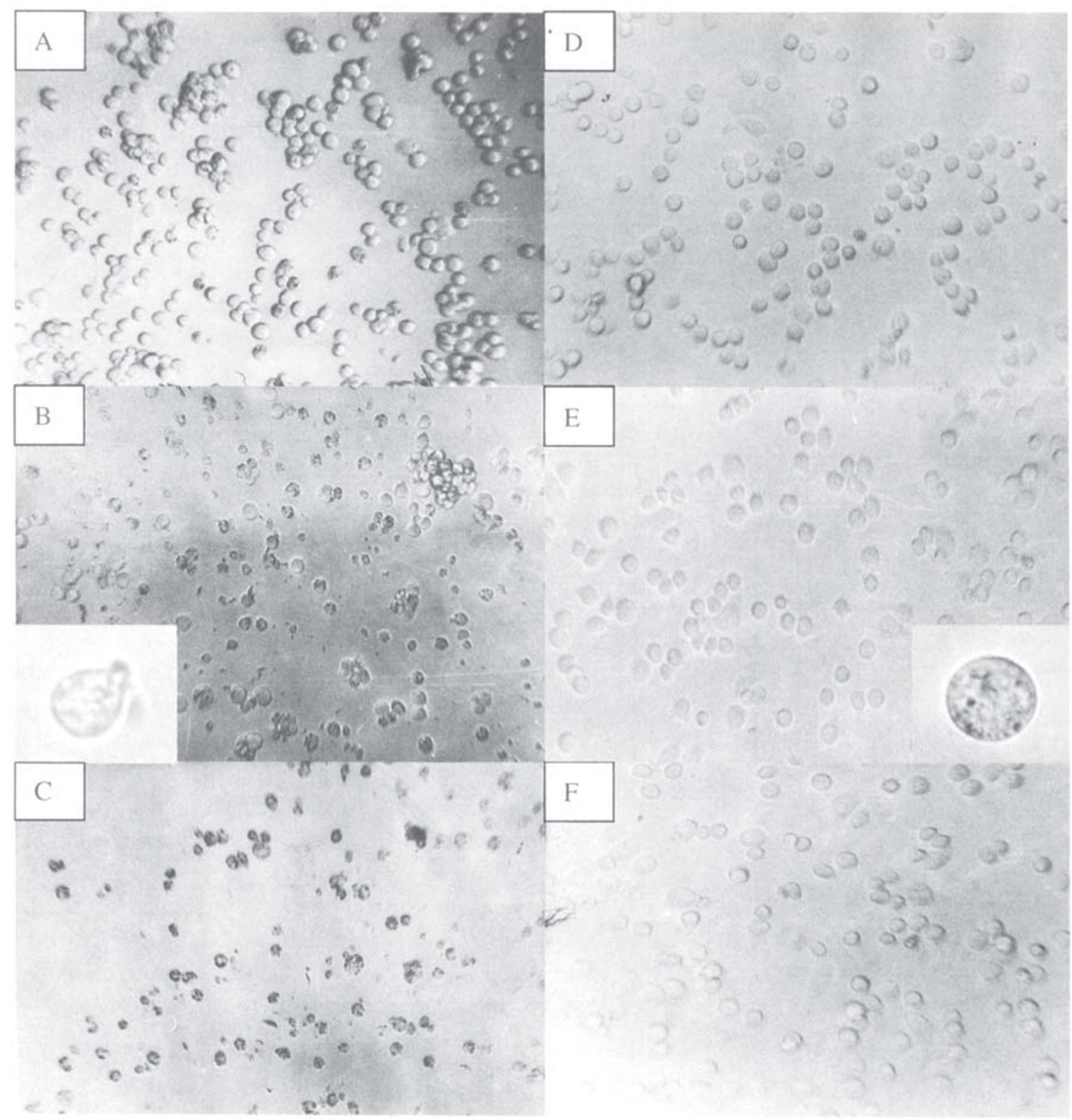

Fig 4. Dosage effect of AaIT toxin on Sf9 insect cells and on MCF-7 human cells. A: Sf9 cells with no AaIT toxin added; B: Sf9 cells treated with $0.013 \mu \mathrm{M}$ AaIT toxin; C: Sf9 cells treated with $0.26 \mathrm{~m}$ M AaIT toxin; D: MCF-7 human cells with no AaIT toxin added; E: MCF-7 human cells treated with $0.13 \mu \mathrm{M}$ AaIT toxin; F: MCF-7 human cells treated with $1.3 \mu \mathrm{M}$ AaIT toxin. Cells were all magnified $\times 100$ except in the insets which were $\times 500$. 
tained in insect resistant transgenic plants which was about $0.05-0.1 \%$ [24-26]. Even with a toxin as potent as AaIT, high level expression was still imperative for transgenic plants to show decent insect resistance. In the cytotoxicity assay, the toxin showed higher toxicity with an LC50 of $0.13 \mu \mathrm{M}$, which was comparable to the cytotoxicity of Wt-hTNFa to the HEp-2 cells[27].

Due to the limitation in the amount of toxin that could be added to the media, we could not obtain an LC50 for cultured human cells (Fig 3). However, it was intriguing to see that $1.3 \mu \mathrm{M}$ toxin had absolutely no effect on the morphology of these human cells while more than $80 \%$ of the cultured insect cells were torn and collapsed in media containing the same amount of toxin (Fig 4). The intrusions from the intoxicated insect cells we observed were similar to the blebbing of the plasma membrane observed from wasp venom toxicity studies[28]. Cohen et al [29] argued that the disruption of the plasma membrane might be due to other components present in their raw venom preparations. However, here we verified that the purified recombinant AaIT toxin was able to disrupt the cell membranes before killing the cells. Since AaIT showed high affinity for the sodium channel in insect neuronal membranes and no affinity at all for the same site in the mammalian neuronal membranes[20], we suggest that AaIT toxin bind specifically to the sodium channel of the cultured insect cells in the similar manner. The binding of the toxin would result in a persistent opening of the sodium channel and the following $\mathrm{Na}^{+}$influx would cause cell blebbing and collapse due to oncosis. The finding that wasp venom increased plasma membrane permeability to $\mathrm{Na}^{+}$, resulting in cellular swelling and death due to oncosis [28],[30], supported our suggestion. In vitro cultured insect and human cell lines may be used to study resistance development and in systemic toxicity evaluation as well.

\section{ACKNOWLEDGEMENTS}

This work was supported by a grant from 863 High Technology Program, Chinese Ministry of Science and Technology.

\section{REFERENCES}

[1] Moskowitz H, Herrmann R, Jones AD, Hammock, BD. A depressant insect-selective toxin analog from the venom of the scorpion Leiurus quinquestriatus hebraeus purification and structure/function characterization. Eur $\mathrm{J}$ Biochem 1998; 254:44-9.

[2] Cest le S, Catterall WA. Molecular mechanisms of neurotoxin action on voltage-gated sodium channels. Biochimie 2000; 82:883-92.

[3] Carbone E, Wanke E, Prestipino G, Possani LD, Maelicke A. Selective blockage of voltage-dependent $\mathrm{K}+$ channels by a novel scorpion toxin. Nature 1982; 296:90-1.

[4] Loret EP, Mansuelle P, Rochat H, Granier C. Neurotoxins active on insects: amino acids sequences, chemical modifications, and secondary structure estimation by circular dichroism of toxins from the scorpion Androctonus australis Hector. Biochemistry 1990; 29:1492-501.

[5] Zlotkin E, Eitan M, Bindokas VP, et al. Functional duality and structural uniqueness of depressant insect-selective neurotoxins. Biochemistry 1991; 30:4814-21.

[6] Catterall WA. The molecular basis of neuronal excitability. Science 1984; 223:653-61.

[7] Zlotkin E, Kadouri D, Gordon D, Pelhate M, Martin MF, Rochat $\mathrm{H}$. An excitatory and a depressant insect toxin from scorpion venom both affect sodium conductance and possess a common binding site. Arch Biochem Biophys 1985; 240: 877-87.

[8] Zhu X, Zhang T, Zhu Y. Cloing and sequencing of two depressant insect neurotoxin cDNAs from Buthus martensii Karsch. Chinese Science Bulletin 1996; 41: 1387-91.

[9] Jiang G, Xu Y, Zhu X, Su Y, Zhu Y. Prokaryotically expressed Buthus martensii Karsch insect depressant toxin has insecticidal effects. Toxicon 2001; 39:469-76.

[10] Li Y, Tan Z, Ji Y. The binding of BmK IT2, a depressant insect-selective scorpion toxin on mammal and insect sodium channels. Neuroscience Research 2000; 38:25764.

[11] Borchani L, Stankiewicz M, Kopeyan C, et al. Purification, structure and activity of three insect toxins from Buthus occitanus tunetanus venom. Toxicon 1997; 35:365-82.

[12] Lester D, Lazarovici P, Pelhate M, Zlotkin E. Purification, characterization and action of two insect toxins from the venom of the scorpion Buthotus judaicus. Biochim Biophys Acta 1982; 701:370-81.

[13] Kopeyan C, Mansuelle P, Sampieri F, et a. Primary structure of scorpion anti-insect toxins isolated from the venom of Leiurus quinquestriatus quinquestriatus. FEBS Lett 1990; 261:423-6.

[14] Eitan M, Fowler E, Herrmann R, Duval A, Pelhate M, Zlotkin E. A scorpion venom neurotoxin paralytic to insects that affects sodium current inactivation: purification, primary structure, and mode of action. Biochemistry 1990; 29:5941-47.

[15] Zlotkin E, Miranda F, Kopeyan C, Lissitzky S. A new toxic protein in the venom of the scorpion Androctonus australis Hector. Toxicon 1971; 9:9-13.

[16] Oren DA, Froy O, Amit E, Kleinberger-Doron N, Gurevitz M, Shaanan B. An excitatory scorpion toxin with a distinctive feature: an additional alpha helix at the $\mathrm{C}$ terminus and its implications for interaction with insect sodium channels. Structure 1998; 6:1095-103.

[17] Gershberg E, Stockholm D, Froy O, Rashi S, Gurevitz M, 
Chejanovsky N. Baculovirus-mediated expression of a scorpion depressant toxin improves the insecticidal efficacy achieved with excitatory toxins. FEBS Lett 1998; 422:132-6.

[18] Zlotkin E, Rochat H, Kopeyan C, Miranda F, Lissitzky S. Purification and properties of the insect toxin from the venom of the scorpion Androctonus australis Hector. Biochimie 1971; 53:1073-8.

[19] Darbon H, Zoltkin E, Kopeyan C, Van Rietschoten J, Rochat H. Covalent structure of the insect toxin of the North African scorpion Androctonus australis Hector. Int J Pept Prot Res 1982; 20:320-30.

[20] Zlotkin E, Fishman Y, Elazar M. AaIT: From neurotoxin to insecticide. Biochimie 2000; 82:869-81.

[21] Oliveira JCR, Montes de Oca H, Duarte MM, Diniz CR, Fortes-Dias CL. Toxicity of South American snake venoms measured by an in vitro cell culture assay. Toxicon 2002; 40:321-5.

[22] Zhang Z, Yao L, Hou Y. Construction and application of a high level expression vector containing PRPL promotor. Chinese Journal of Virology 1990; 6:111-6.

[23] Hurt JD, Tu C, Laipis PJ. Isolation and expression of murine carbonic anhydrase IV. Protein Expression and Purification 1998; 12:7-16.

[24] Iannacone R, Grieco PD, Cellini F. Specific sequence modifications of a cry3B endotoxin gene result in high levels of expression and insect resistance. Plant Molecu- lar Biology 1997; 34:485-96.

[25] Kota M, Daniell H, Varma S, Garczynski SF, Gould F, Moar WJ. Overexpression of the Bacillus thuringiensis (Bt) Cry2Aa2 protein in chloroplasts confers resistance to plants against susceptible and Bt-resistant insects. Proc Natl Acad Sci USA 1999; 96:1840-5.

[26] Huang J, Wei Z, An H, Zhu Y. Agrobacterium tumefaciensmediated transformation of rice with the spider insecticidal gene conferring resistance to leaffolder and striped stem borer. Cell Research 2001; 11(2):149-55.

[27] Lu F, Fang J, Chen C. TNF receptor-associated factor-2 binding site is involved in TNFR75-dependent enhancement of TNFR55-induced cell death. Cell Research 2001; 11(3):217-22.

[28] Rivers DB, Rocco MM, Frayha AR. Venom from the ectoparasitic wasp Nasonia vitripennis increases $\mathrm{Na}+$ influx and activates phospholipase $\mathrm{C}$ and phospholipase A2 dependent signal transduction pathways in cultured insect cells. Toxicon 2002; 40:9-21.

[29] Cohen E, Quistad GB. Cytotoxic effects of arthropod venoms on various cultured cells. Toxicon 1998; 36:353-8.

[30] Rivers DB, Genco M, Sanchez RA. In vitro Analysis of Venom from the Wasp Nasonia Vitripennis: Susceptibility of Different Cell Lines and Venom-Induced Changes in Plasma Membrane Permeability. In vitro Cell Dev Biol-Animal 1998; 35:102-10. 